\title{
Readings in the Economics Division of Labor: The Classical Tradition
}




\section{Increasing Returns and Inframarginal Economics}

Series Editors: James Buchanan, Yew-Kwang Ng, (Xiaokai Yang)

Associate Editor: Guang-Zhen Sun

\section{Published}

Vol. 1 An Inframarginal Approach to Trade Theory

Edited by Xiaokai Yang, Wenli Cheng, Heling Shi \&

Christis G. Tombazos

Vol.2 Readings in the Economics of the Division of Labor: The Classical Tradition

Edited by Guang-Zhen Sun 
Increasing Returns and Inframarginal Economics - Vol. 2
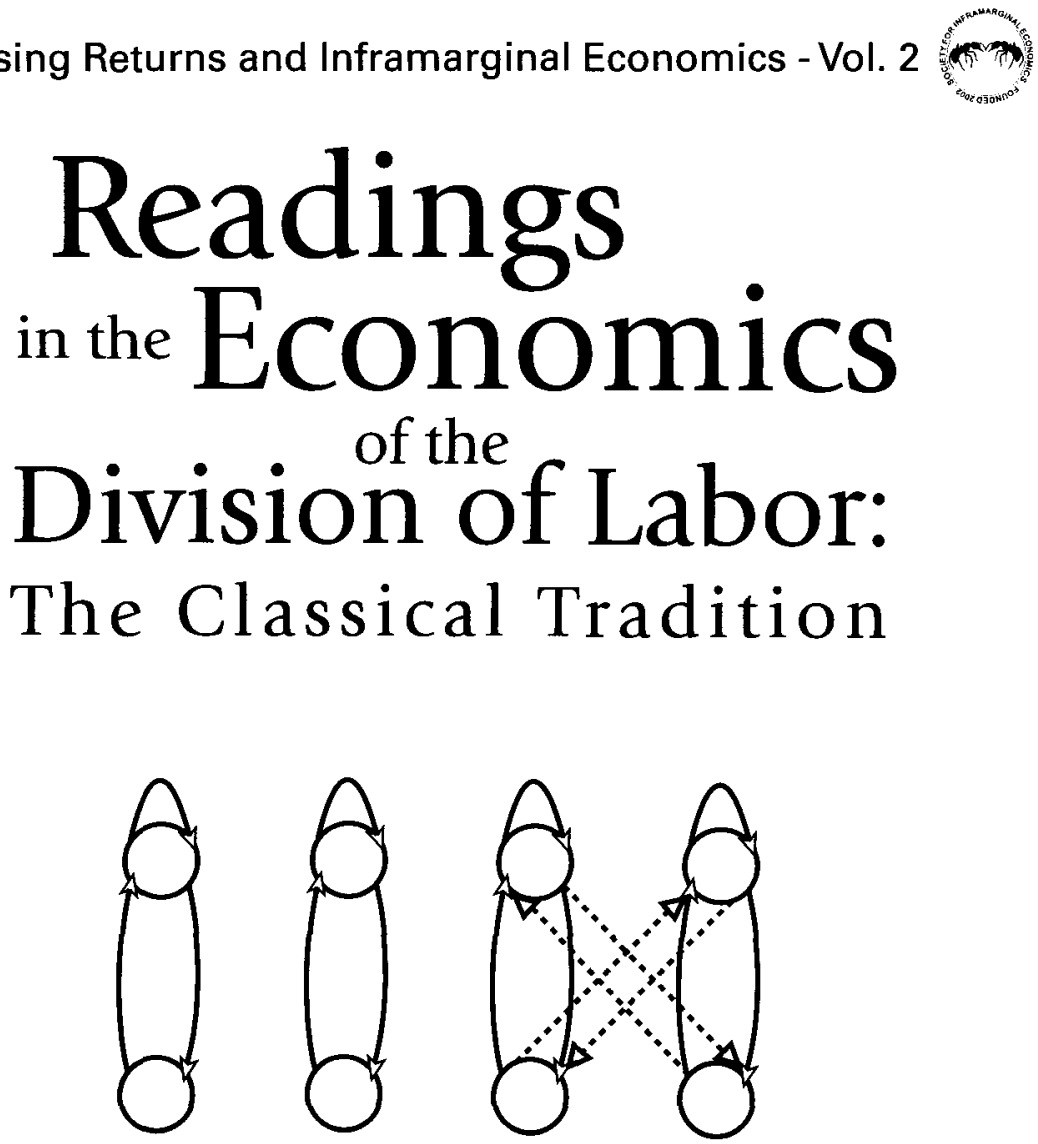

edited by

\section{Guang-Zhen Sun Monash University, Australia}


Published by

World Scientific Publishing Co. Pte. Ltd.

5 Toh Tuck Link, Singapore 596224

USA office: 27 Warren Street, Suite 401-402, Hackensack, NJ 07601

UK office: 57 Shelton Street, Covent Garden, London WC2H 9HE

\section{British Library Cataloguing-in-Publication Data}

A catalogue record for this book is available from the British Library.

\section{READINGS IN THE ECONOMICS OF THE DIVISION OF LABOR: THE CLASSICAL TRADITION}

Copyright $(1) 2005$ by Guang-Zhen Sun

All rights reserved. This book, or parts thereof, may not be reproduced in any form or by any means, electronic or mechanical, including photocopying, recording or any information storage and retrieval system now known or to be invented, without written permission from the Publisher.

For photocopying of material in this volume, please pay a copying fee through the Copyright Clearance Center, Inc., 222 Rosewood Drive, Danvers, MA 01923, USA. In this case permission to photocopy is not required from the publisher.

ISBN $981-256-124-2$

Printed in Singapore. 


\section{Preface}

Since the late 1970s ---- about half a century after Sraffa's (1926, The Economic Journal) devastating analysis of the notorious difficulty in accommodating increasing returns into a competitive equilibrium framework ---- there has been an increasing interest in economics of specialization and the division of labor, which is deservedly referred to as "Return to Increasing Returns" (James Buchanan and Yong J. Yoon (Eds.), The Return to Increasing Returns. University of Michigan Press 1994). That may be not surprising, for the division of labor is necessarily associated with increasing returns. Only quite recently did economic theorists successfully demonstrate the comparability between generalized increasing returns to the division of labor and competitive equilibrium. Some authors even simply discard the general equilibrium framework altogether in studying the progressive division of labor by instead working with alternative evolutionary models.

Regardless of the difference and/or disagreement in methodology and emphasis among students of the division of labor, the profound implications of the emergent order of the division of labor from within the economic system for economic progress in general has been recognized and explored by more and more economists in the recent two decades (see, e.g., Buchanan and Yoon 1994; Kenneth Arrow etc. (eds.) Increasing Returns and Economic Analysis. Macmillan 1998; and Geoffrey Heal (ed.), The Economics of Increasing Returns, Edward Elgar 1999). Yet, much more remains to be understood, and it may be fair to say that the study of the (progressive) division of labor is still a burgeoning industry. In fact, some authors (e.g., George Stigler 1976, 
Journal of Political Economy) go as far as to predict that topics related to the division of labor may keep economists busy for many decades to come.

On the other hand, classical authors, even dating back as early as 500 $\mathrm{BC}$ have indeed made insightful analyses on the determinants and implications of the division of labor, which unfortunately are rather scattered and not readily accessible to many economists who have great interest in the economics of specialization. The project of Readings of Economics of the Division of Labor, of which this book is the first volume, aims to fill this void in the book market, serving as a reference for scholars interested in the division of labor. Under this Readings project, three volumes will be edited. Volume One, the current one, covers the Classical Tradition, dating from Xenophon and Plato till the modern Austrian economics represented by F. A. Hayek in 1930s-1940s. Volume Two puts together selected modern economic analyses largely since post WWII till the early 2000s. Volume Three focuses on theories and insights contributed from neighboring disciplines including sociology, philosophy, anthropology, etc. The three volumes, complementary though as they stand, are largely independent from one another, and each can therefore be used independently for its own interest.

This volume begins with the precursors of political economy including the ancient Greeks, medieval Islamic scholastics and mercantilists, continues with the classical political economists and the neoclassicists, and concludes with Hayek's economics of dispersed knowledge well into 1940s. It covers major themes and perspectives about the division of labor that have emerged in the discipline of the economic science till WWII. As such, it is intended that this volume can well serve as a handy reference book for economists of the division of labor, as well as a supplementary text on courses in history of economic thought, labor economics, development economics, etc. for both the graduate and undergraduate levels.

No "Readings" book can claim to be comprehensive. This book is no exception. Indeed, bearing in mind that a book on the classical tradition in economics of the division of labor can never be exhaustive in coverage due to the very nature of the topic, we intentionally make this book rather 
selective and short, in the hope that the reader can thereby readily grasp the main themes in classical studies of division of labor. We must apologize for omission of any pieces that appear important to some readers.

Minor alternations, exclusively in style, have been made in several chapters from their original sources, dating centuries back, not only for purpose of consistency but also for convenience in modern readership.

G.-Z. Sun

Dec. 2004 
This page is intentionally left blank 


\section{Acknowledgement}

The editor should like to thank the following for permission to reproduce copyright material:

Xenophon, Oeconomicus, Translated by Sarah B. Pomeroy, Clarendon Press. Oxford, 1994, pp.141, 143, 145 and 147.

Plato, Complete Works, Edited by John M. Cooper and D. S. Hutchinson, Hackett Publishing Company, Inc., 1997, book II, p100813.

Aristotle, The Works of Aristotle, Vol. X, Edited by W. D. Ross, Benjamin Jowett, E. S. Forster and Frederic G. Kenyon, Clarendon Press. Oxford, 1921, book I, p1257a-1257b

Ibn Khald n, The Muqaddimah: An Introduction to History, 3 Volumes, Translated by Franz Rosenthal. Bollingen Series XLIII, Pantheon Books, New York, 1958, Vol.1, pp. 89-90; and Vol.2, pp. 271-2, 276-8, 313-4, 346-7 and 351.

Bernard Mandeville, The Fable of The Bees: or, Private Vices, Publick Benefits, With a Commentary Critical, Historical, and Explanatory by F. B. Kaye, Clarendon Press. Oxford, 1957, VOL. 1, pp356-8; VOL. 2, pp.141-7, p284

Adam Ferguson, An Essay on the History of Civil Society, Edited by Fania OZ-Salzberger, Cambridge University Press, 1995, pp1725 .

Adam Smith, An Inquiry into the Nature and Causes of the Wealth of Nations, Edited by R. H. Campbell, A. S. Skinner and W. B. Todd, Clarendon Press, Oxford, 1976, Vol. 1, pp. 13-44, 277, 377-8, 446-8; and Vol. 2, pp.781-4 (text only, without notes). 
Charles Babbage, The Economy of Machinery and Manufactures, Edited by Martin Campbell-Kelly, William Pickering, London, 1989, Volume 8, pp121-5, 130-40 and 143.

Karl Marx, Capital, Translated by Ben Fowkes, Penguin Books in association with New Left Review (Edition and Notes copyright holder), 1976, Volume One, pp. 470-80.

Alfred Marshall, Principles of Economics, Alfred Marshall, Ninth Edition, Macmillan and Co Limited, New York, 1961, pp.240-1, 25066 and 318-22.

Piero Sraffa, "The Laws of returns under Competitive Conditions", The Economic Journal (Blackwell Publishing), No. 144(Vol. XXXVI December 1926), pp. 535-50.

Allyn Young, "Increasing Returns and Economic Progress", The Economic Journal (Blackwell Publishing), No.152(Vol. XXXVIII 1928), pp.527-42.

Carl Menger, "On the Origin of Money", The Economic Journal (Blackwell Publishing), No.6 (Vol. II 1892), pp. 239-55.

Friedrich A. Hayek, "The Use of Knowledge in Society", American Economic Review (the American Economic Association), No.4 (Vol. XXXV September 1945), pp. 519-30.

Every effort has been made to contact copyright holders but if any have been inadvertently overlooked the editor will be grateful to be informed and thereby to make the necessary arrangement at the first opportunity.

Excellent research assistance from Miss Ye Deng and Mr. Dean Liu, especially in preparing the camera-ready manuscript copy of the book, is greatly appreciated. My thanks also go to Chean Chian Cheong and Yubing Zhai of the World Scientific Publishing Co. for their support and assistance with this project. Of course, neither of them holds responsibility for any remaining errors. The editor should also like to gratefully acknowledge the support from the Logan Fellowship and the Research Committee of Department of Economics, both at Monash University. 


\section{Contents}

Preface v

Acknowledgement $\quad$ ix

\section{Part I. Introduction}

1. The Economics of Division of Labor from Xenophon to Hayek (1945): A Review of Selected Literature Guang-Zhen Sun

Part II. Nothing New under the Sun? Pieces up to Adam Smith Ancient Greek Wisdoms

2. From Cyropaedia and Oeconomicus Xenophon

3. From The Republic

Plato

4. From Politica

Aristotle

$\underline{\text { Medieval Islamic Insights }}$

5. From The Muqaddimah

Ibn Khaldũn 


\section{Emergence of Political Economy of the Division of Labor}

6. From Political Arithmetic and Another Essay on Political Arithmetic: Concerning the Growth of the City of London William Petty

7. From Considerations upon the East-India Trade

Henry Martyn ("the anonymous")

8. From The Fable of the Bees

Bernard Mandeville

9. From "Art" in Encyclopedie

Diderot and d'Alembert

10. From A System of Moral Philosophy

Francis Hutcheson

11. From An Essay on the History of Civil Society

Adam Ferguson

12. From Reflections on the Formation and Distribution of Riches Anne Robert Jacques Turgot

13. From An Inquiry into the Nature and Causes of the Wealth of Nations

Adam Smith

\section{Part III. Classical Political Economy}

14. From The Principle of Political Economy and Taxation David Ricardo

15. From The Economy of Machinery and Manufactures

Charles Babbage

16. From The Philosophy of Manufactures

Andrew Ure 
17. From A Commentary on An Inquiry into the Nature and Causes of the Wealth of Nations

Edward Gibbon Wakefield

18. From Principles of Political Economy

John Stuart Mill

19. From Capital

Karl Marx

20. From Science of Wealth

Amasa Walker

188

Part IV. Marshallian Economics

21. From Principles of Economics

Alfred Marshall

22. The Laws of Returns under Competitive Conditions

Piero Sraffa

23. Increasing Returns and Economic Progress

Allyn Young

\section{Part V. The Austrian Insights}

25. On the Origin of Money

Carl Menger

25. The Use of Knowledge in Society

Friedrich A. Hayek

Name Index 